Original Article

\title{
RUTIN RESTORE BIOCHEMICAL CHANGES, OXIDATIVE STRESS AND BETATROPHIN LEVEL IN STZ-INDUCED DIABETIC RATS
}

\author{
AL-SHIMAA M. ABAS'1, AHMED F. EL-FARARGY², NEHAL W. ABDALLA1 ${ }^{1}$ \\ ${ }^{1}$ Biochemistry Division, Chemistry Department, Faculty of Science, Zagazig University, Egypt, ${ }^{2}$ Chemistry Department, Faculty of Science, \\ Zagazig University, Egypt \\ Email: dr_shmma@yahoo.com \\ Received: 08 Aug 2019, Revised and Accepted: 10 Oct 2019
}

\begin{abstract}
Objective: Diabetes mellitus (DM) is associated with long-term damage, dysfunction, of various organs. Study aims to assessrole of rutin on experimentally induced diabetes.

Methods: 50 adult male albino rats divided into 5 groups. Group I (control group, rats were orally administered with $1 \mathrm{ml}$ saline daily). Group II (DMSO group, rats were orally administered with $0.2 \%$ DMSO for $60 \mathrm{~d}$ orally). Group III (positive control, animals were injected intraperitoneally with 60 $\mathrm{mg} / \mathrm{kg}$ b. wtstreptozotocin followed by intraperitoneal injection with $120 \mathrm{mg} / \mathrm{kg} \mathrm{b}$. wt of Nicotinamide after $15 \mathrm{~min}$ ). Group IV (therapeutic group, diabetic rats treated with $100 \mathrm{mg} / \mathrm{kg} \mathrm{b}$. wt of rutin for $60 \mathrm{~d}$ orally). Group V (standard group, diabetic animals treated with $100 \mathrm{mg} / \mathrm{kg}$ b. wt of metformin for $60 \mathrm{~d}$ orally). At the end of the experimental period blood serum and plasma, liver, kidney and pancreatic tissues were collected.
\end{abstract}

Results: Diabetic rats showed a significant increase in plasma glucose, serum urea, creatinine, cholesterol and triglyceride. Also, induced oxidative stress as pointed out an increase in MDA level, decrease in GSH level, GST and CAT activities in compared to control group. Also, showed an increase in plasma and tissues levels of betatrophin. Oral administration of rutin cause decrease in elevated biochemical and oxidative stress parameters. Also, decrease betatrophin level when compared with diabetic rats. Our results were confirmed by histopathological examination of different tissues.

Conclusion: This study suggests that rutin exihibit santihyperglycemic and antioxidant activity in streptozotocin-induced diabetic rats.

Keywords: Diabetes mellitus, STZ, Rutin, Betatrophin

(C) 2019 The Authors. Published by Innovare Academic Sciences Pvt Ltd. This is an open-access article under the CC BY license (http://creativecommons.org/licenses/by/4.0/] DOI: http://dx.doi.org/10.22159/ijcpr.2019v11i6.36344

\section{INTRODUCTION}

Diabetes mellitus (DM) is one of the most important health problems in all world. It is the seventh cause of death all over the world [1]. It was documented that $25 \%$ of the world population having DM.

DM is a metabolic disease characterized by chronic high blood glucose with an imbalance in metabolism of carbohydrates, proteins and fat caused by impair in insulin secretion, insulin action, or both. It is symptoms were thirst, urination, impair vision, and decrease in weight.

Streptozotocin (STZ) is a deoxy-s [((methyl-nitrosoamino) carbonyl) -amino]-D glucopyranose molecule that caused toxic action on $\beta$ cells and induced DM in most laboratory animals [2]. STZ enters the pancreatic $\beta$-cells through a glucose transporter-GLUT2 and induces alkylation of genetic material DNA. In addition to, STZ caused activation of poly adenosine diphosphate (ADP) ribosylation and nitric oxide (NO) release. Finally of STZ action caused pancreatic $\beta$ cells destroy by necrosis. The real mechanism of its toxicity is still unclear, it is proposed that site of action is at nuclear DNA. Through the STZ metabolism, highly reactive carbonium ions $\left(\mathrm{CH}^{5}\right)$ are produced, that induce alkylation of DNA bases and also STZ may damage the membrane of $\beta$ cell and break the DNA strand which causes activation of poly (ADP-ribose) synthetase and NAD decrease, which leads to cell death [3].

Rutin (rutoside, quercetin-3-0-rutinoside) is 2-(3,4-dihydroxyphenyl)-5,7-dihydroxy-3-[ $\alpha$-L-rhamnopyranosyl-(1 6 ( 1 - $\beta$-Dglucopyranosyloxy]-4H-chromen-4-one. It is classified as a polyphenolic flavonoid (fig. 1). It is found in different plants and food products of plant origin. Rutin appears as an odorless yellow crystalline powder that is practically insoluble in $\mathrm{H} 2 \mathrm{O}$ and poorly soluble in alcohol [4]. Living organisms are unable to synthesize rutin. Therefore, it can only be ingested and destroyed with plant products. Rutin and its aglycones were found in various fruits, vegetables, tea leaves, coffee grains, etc. [5].
Rutin is considered to be a very good antioxidant because of its ability to bind free radicals and metal ions [6]. Rutin is capable of chelating iron ions (II and III valence), which can initiate oxygen free-radical formation [7]. The aglycone of rutin has a protective effect by binding to free radicals during reperfusion injury of ischemic tissues [8]. Rutin can also be used as an anti-inflammatory agent because of binding of free radicals that prevents the induction of inflammatory cytokine transcription factors [9]. Thus, rutinis important in treatment chronic inflammatory diseases [10].

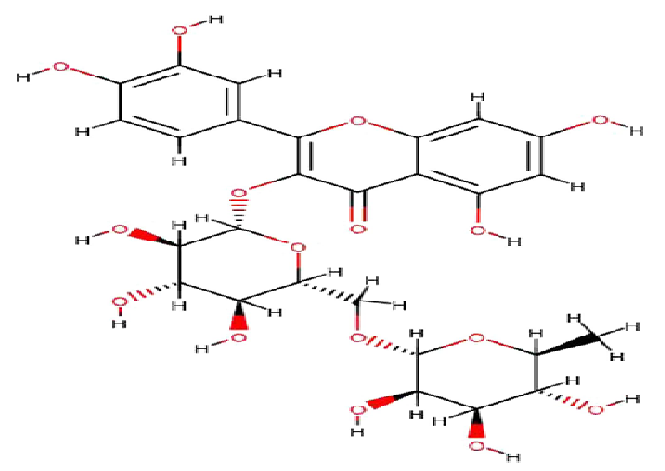

Fig. 1: Chemical structure of rutin

\section{MATERIALS AND METHODS}

\section{Animal management}

Adult male albino rats, weighing 180-200 g, were obtained from the Experimental Animal Care Center from Cairo university and were keeped in cages at experimental animal house of faculty of Science, 
Zagazig University under regulated environmental conditions $\left(25^{\circ} \mathrm{C}\right.$ and a $12 \mathrm{~h}$ light/dark cycle) $7 \mathrm{~d}$ before starting the experiment.

\section{Diabetic model}

Diabetes was induced by STZ, purchased from Sigma Chemical Co. (St. Louis, MO, USA).

Induction of Type 2 diabetes $\left(\mathrm{T}_{2} \mathrm{DM}\right.$ ) by single intraperitoneal (i. P) injection of STZ at a dose of $60 \mathrm{mg} / \mathrm{kg} \mathrm{b}$. wt in fasting rats followed by the i. P injection of nicotinamide (NIC) at a dose of $120 \mathrm{mg} / \mathrm{kg} \mathrm{b}$. wt after $15 \mathrm{~min}$. STZ was dissolved in freshly prepared cold citrate buffer ( $100 \mathrm{mmol}, \mathrm{pH}=4.5)$ to immediate use through five minutes. While nicotinamide was dissolved in $0.9 \%$ saline of sodium chloride [11]. Blood glucose levels in all animals were measured after $72 \mathrm{~h}$ of drug administration and rats of fasting blood glucose levels higher than $250 \mathrm{mg} / \mathrm{dl}$ were considered to be diabetic and used for the further study [12].

\section{Rutin dose selection and treatment}

Rutin was obtained from Sigma Chemical Co (St. Louis, MO, USA).

The rats were orally administrated with Rutin at a dose of 100 $\mathrm{mg} / \mathrm{kg}$ each day dissolved in $0.2 \%$ DMSO [13].

\section{Experimental design}

To accomplish the ultimate goal of this study, after the acclimatization period of $7 \mathrm{~d}$ with a standard basal diet, a total of 50 adult male albino rats were classified into five groups with 10 animals in each group.

Group I (control Group): Rats were administrated orally with $1 \mathrm{ml}$ single saline dose.

Group II (DMSO group): Rats were administrated by gavaging $1 \mathrm{ml}$ of $0.2 \%$ DMSO for $60 \mathrm{~d}$.

Group III (Positive control): Rats received STZ (60 mg/kg b. wt) followed by the i. p administration of Nicotinamide $(120 \mathrm{mg} / \mathrm{kg} \mathrm{b}$. wt) after $15 \mathrm{~min}$.

Group IV (Therapeutic Group):Rats were induced for DM. After $1 \mathrm{w}$ of DM induction, animals were post-treated with Rutin $(100 \mathrm{mg} / \mathrm{kg}$ daily for $60 \mathrm{~d}$ orally) [13].

GroupV (standard therapeutic): were induced for DM. After $1 \mathrm{w}$ of DM induction, animals were post-treated with metformin (100 $\mathrm{mg} / \mathrm{kg}$ daily for $60 \mathrm{~d}$ orally [14].

Doses of rutin and metformin were adjusted every week according to any change in body weight to maintain the same dose per each kg body weight of rat during the entire period of study for each group.

\section{Collection and sampling of blood}

At the end of the study and after last treatment, rats were fasted for $12 \mathrm{~h}$; blood samples were collected from the retro-orbital venous plexus under light ether anesthesia. Where blood samples were collected in three different tubes, first tube containing sodium fluoride for blood glucose estimation, second tube containing EDTA to obtain plasma and third empty tube to obtain serum by centrifugation at $4000 \mathrm{rpm}$ for $20 \mathrm{~min}$. Serum and plasma were transferred into eppendorff tubes and stored frozen at- $20{ }^{\circ} \mathrm{C}$ til an analysis of different biochemical measurements (glucose, liver, kidney lipid function tests and betatrophin).

\section{Tissue sample}

After blood collection, animals were killed by cervical decapitation and different tissues (liver, kidney, and pancrease) were excised from animals, rinsed in with ice-cold phosphate-buffered saline $\mathrm{cH}$ 7.4) to flush out any blood.

The first part of different tissue samples was homogenized with icecold phosphate-buffered saline $(\mathrm{pH} 7.4)$ to prepare a $10 \%(\mathrm{w} / \mathrm{v})$ tissue homogenate for determination MDA and GSH levels. Also, CAT and GST activities and estimation of level of betatrophin.

Second part of different tissue samples was used for histopathological study.

\section{Biochemical analysis}

\section{- Estimation of biochemical parameters}

Plasma glucose was performed by glucose oxidase peroxidase activity using commercial kit derived from Elitech clinical system, france[15]. Serum urea was measured by Berthelot emzymatic colorimetric method [16] and creatinine was measured by Buffered kinetic jaffè reaction without deproteinization [17]. Also serum cholesterol concentration was determinated by CHOD-POD enzymatic colorimetric method [18] while serum triglyceride concentration was measured by GPO-PAP enzymatic colorimetric method [19].

\section{- Oxidant and antioxidant parameters}

The tissue levels of MDA [20], GSH [21], activity of GST [22] and catalase [23] and [24] were determined using kits purchased from BiodiagnosticCompany (Biodiagnostic, Egypt).

\section{- Estimation of betatrophin}

Betatrophin was determined by enzyme-linked immunosorbant assay (ELISA). Rat Angiopoietin Like Protein 8 Immunoassay Kit, (Catalog Number 201-11-1795) purchased from SunRed Biotechnology Company.

\section{Histopathological examination}

Different tissues were then immersed with molted paraffin wax, then embedded and blocked out. Paraffin sections (4-5 um) were stained with hematoxylin and eosin then examined through light electric microscope [25].

\section{Statistical analysis}

All results were analyzed by SPSS software (SPSS, ver.14.00, USA). Data were expressed as mean \pm SEM. Comparison of mean values of studied variables among different groups was done using ANOVA test. $\mathrm{P}<0.05$ was considered to be significant [26].

\section{RESULTS}

\section{Effect of rutin on body weight}

The initial and final body weight was given in (table 1). There was significant decrease $(p<0.001)$ in finial body weight of diabetic induced group (positive group) which amounted to-31.29 \% when compared to control group, while groups treated with rutin and metformin showed slight decrease in the final body weight which was statistically non-significant in compared to control group which amounted to- $6.77 \%$ and $-2.9 \%$ respectively $(\mathrm{P}>0.05)$.

Table 1: Body weight of different studied groups.

\begin{tabular}{lll}
\hline Groups & Initial body weight (g) & Final body weight (g) \\
\hline Control mean \pm SEM & $177 \pm 2.88$ & $310 \pm 5.48$ \\
DMSO mean SEM \% change & $177 \pm 1.67$ & $312 \pm 8.7$ \\
Positive (STZ-induced) mean \pm SEM \% change & $182 \pm 7.4$ & $213 \pm 2.18^{* * *}$ \\
Metformin mean \pm SEM \% change & $170 \pm 7.67$ & $301 \pm 4.53$ \\
Rutin mean \pm SEM \% change & $172 \pm 2.4$ & $289 \pm 8.2$ \\
P value & $\mathrm{P}>0.05$ & $\mathrm{P}<0.001$ \\
\hline
\end{tabular}

${ }^{*} \mathrm{P}<0.05$ compared to control group, ${ }^{* *} \mathrm{P}<0.01,{ }^{* *} \mathrm{P}<0.001$ compared to control group. The mean difference is significant at $\mathrm{P}<0.05 . \%$ change $=$ Percent of change compared to control group. 


\section{Effect of rutinon biochemical parameter}

Result presented in (table 2) declared that positive control group showed high elevation in plasma glucose, serum urea, creatinine, cholesterol and triglyceride ( $\mathrm{p}>0.001$ ) which amounted to $199.1 \%$ $97.6 \%, 36.84 \%, 38.57 \%$ and $99.47 \%$ respectively when compared to control group. On the other hand groups treated with rutin (therapeutic) and metformin (standard) showed good improvement in these parameters which amounted to $10.8 \%, 28.2 \%,-15.78 \%$ $8.09 \%$ and $1.32 \%$ respectively in metformin and $11.6 \%, 41.17 \%$,$13.6 \%, 11.4 \%$ and $3.83 \%$ respectively in rutin $(\mathrm{p}<0.05)$ in comparison with control group.

Table 2: Effect of rutin on biochemical parameter

\begin{tabular}{|c|c|c|c|c|c|}
\hline Groups & Glucose(mg/dl) & Urea(mg/dl) & Creatinine(mg/dl) & Cholesterol(mg/dl) & Triglyceride(mg/dl) \\
\hline Control mean \pm SEM & $120 \pm 6.6$ & $42.5 \pm 5.4$ & $0.95 \pm 0.02$ & $105 \pm 5.8$ & $378.5 \pm 3.7$ \\
\hline DMSO mean $\pm S E M \%$ change & $125 \pm 1.44 .16 \%$ & $41.2 \pm 3.13-3.0 \%$ & $0.84 \pm 0.04-11.57 \%$ & $106.4 \pm 5.71 .3 \%$ & $377.2 \pm 19.2-0.34 \%$ \\
\hline $\begin{array}{l}\text { Positive (STZ-induced) } \\
\text { mean } \pm \text { SEM \% change }\end{array}$ & $359 \pm 1.5^{* * *} 199.1 \%$ & $84 \pm 1.2^{* * *} 97.6 \%$ & $1.3 \pm 0.11^{* *} 36.84 \%$ & $145.5 \pm 0.9^{* * *} 38.57 \%$ & $775 \pm 0.5^{* * *} 99.47 \%$ \\
\hline $\begin{array}{l}\text { Met for min mean } \pm \text { SEM } \% \\
\text { change }\end{array}$ & $133 \pm 3.1^{*} \mathrm{c} 10.8 \%$ & $54.5 \pm 1.7$ с $28.2 \%$ & $0.80 \pm 0.05^{c-15.78} \%$ & $113.5 \pm 2.1^{\mathrm{c}} 8.09 \%$ & $383.5 \pm 19.9$ c1.32 \% \\
\hline Rutin mean \pm SEM $\%$ change & $134 \pm 3.5^{*} \mathrm{c} 11.6 \%$ & $60 \pm 5.5^{*} \mathrm{~b} 41.17 \%$ & $0.82 \pm 0.03^{c}-13.6 \%$ & $116.7 \pm 2.7^{b} 11.4 \%$ & $393 \pm 6.8 \div 3.83 \%$ \\
\hline$P$ value & $\mathrm{P}<0.001$ & $P<0.001$ & $\mathrm{P}<0.001$ & $\mathrm{P}<0.001$ & $\mathrm{P}<0.001$ \\
\hline
\end{tabular}

${ }^{*} \mathrm{P}<0.05$ compared to control group, ${ }^{* *} \mathrm{P}<0.01$, ${ }^{* * *} \mathrm{P}<0.001$ compared to control group. a $\mathrm{P}<0.05$, bP $<0.01$, c $\mathrm{P}<0.001$ compared to positive control group. The mean difference is significant at $\mathrm{P}<0.05$. \% change $=$ Percent of change compared to control group.

\section{Effect of rutinon oxidative and antioxidative parameters}

\section{- pancreatic tissue}

Our result presented in (table 3) showed that positive control group caused significant increase in level of MDA which amounted to $29.8 \%$ ( $>0.001)$ and marked decrease in the activity of GST, CAT ( $>00.01)$ and level of GSH ( $p>0.05$ ) which amounted to $32.89 \%,-8.87 \%$ and$18.09 \%$ respectively when compared to the control group.
Meanwhile groups treated with rutin (therapeutic) and metformin (standard) reduced the elevation in MDA which amounted to $13.59 \%$ and $4.38 \%$ respectively $(\mathrm{p}<0.05)$ when compared to control group. Also, increased the the values of GST, CAT and GSH which showed slight decreasein compared to control group which amounted to-15.78 \%,-4.77 \%,-9.5 \% respectively in rutin and-5.26\%,-0.34\%,-2.85\% respectively in metformin.

Table 3: Effect of rutin on oxidative and antioxidant levels in pancreatic tissue

\begin{tabular}{|c|c|c|c|c|}
\hline Groups & MDA (nmol/g) & Catalase (U/g) & GST(U/g) & GSH(mg/g) \\
\hline Control mean \pm SEM & $22.8 \pm 0.54$ & $7.6 \pm 1.6$ & $29.3 \pm 1.1$ & $21.0 \pm 0.3$ \\
\hline DMSO mean \pm SEM $\%$ change & $23.0 \pm 0.670 .87 \%$ & $7.4 \pm 1.1-2.6 \%$ & $28.1 \pm 0.88-4.09 \%$ & $20.9 \pm 0.6-0.47 \%$ \\
\hline $\begin{array}{l}\text { Positive (STZ-induced) } \\
\text { mean } \pm \text { SEM \% change }\end{array}$ & $29.6 \pm 0.66^{* * *} 29.8 \%$ & $5.1 \pm 0.45^{* *}-32.89 \%$ & $26.7 \pm 0.62^{* *}-8.87 \%$ & $17.2 \pm 0.64^{* *}-18.09 \%$ \\
\hline $\begin{array}{l}\text { Metformin mean } \pm \text { SEM } \% \\
\text { change }\end{array}$ & $23.8 \pm 0.34 c 4.38 \%$ & $7.2 \pm 0.88^{\mathrm{b}}-5.26 \%$ & $29.2 \pm 1.2^{\mathrm{b}}-0.34 \%$ & $20.4 \pm 0.9 \mathrm{~b}-2.85 \%$ \\
\hline Rutin mean \pm SEM $\%$ change & $25.9 \pm 0.59^{*} \mathrm{c} 13.59 \%$ & $6.4 \pm 0.24-15.78 \%$ & $27.9 \pm 0.92-4.77 \%$ & $19.0 \pm 0.5-9.5 \%$ \\
\hline $\mathrm{P}$ value & $\mathrm{P}<0.001$ & $\mathrm{P}<0.05$ & $\mathrm{P}<0.05$ & $\mathrm{P}<0.05$ \\
\hline
\end{tabular}

${ }^{*} \mathrm{P}<0.05$ compared to control group, ${ }^{* *} \mathrm{P}<0.01,{ }^{* * *} \mathrm{P}<0.001$ compared to control group. a $\mathrm{P}<0.05$, b $\mathrm{P}<0.01$, c $\mathrm{P}<0.001$ compared to positive control group. The mean difference is significant at $\mathrm{P}<0.05 . \%$ change $=$ Percent of change compared to control group.

\section{- liver tissue}

Hepatic antioxidant levels were showed in (table 4). In positive group mean level of MDA was significantly increased $(22.11 \%, \mathrm{P}>0.01)$ when compared with control group. While there was significant decrease in CAT $(-15.5 \%, \mathrm{p}=0.001)$, GST $(-22.67 \%, \mathrm{P}>0.001)$ activities and GSH ($12.23 \%, \mathrm{P}>0.01$ ) level when compared to control group.

Mean while, groups treated with rutin and metformin showed slight non-significant increase of MDA levels which amounted to
$6.57 \%$ and $4.38 \%$ respectively $(\mathrm{p}<0.05)$ when compared to control group.

Also, rutin declared slight decrease in CAT, GST activities which amounted to-2.6 \%,-1.36 \% respectively and GSH level which amounted to-1.04\% $(\mathrm{P}>0.05)$ when compared to control group. While metformin showed decrease in CAT $(-5.88 \%, \mathrm{p}<0.05)$, GST ($13.09 \%, p>0.01)$ activities and GSH level $(-5.24 \%, p>0.05)$ when compared to control group.

Table 4: Effect of rutin on oxidative and antioxidant levels in liver tissue

\begin{tabular}{|c|c|c|c|c|}
\hline Groups & MDA (nmol/g) & Catalase (U/g) & GST(U/g) & GSH(mg/g) \\
\hline Control mean \pm SEM & $50.2 \pm 1.9$ & $18.7 \pm 0.49$ & $102.3 \pm 3.1$ & $28.6 \pm 0.2$ \\
\hline DMSO mean \pm SEM $\%$ change & $51.0 \pm 3.91 .59 \%$ & $18.6 \pm 0.18-0.53 \%$ & $101.4 \pm 2.4-0.8 \%$ & $28.3 \pm 1.0-1.04 \%$ \\
\hline $\begin{array}{l}\text { Positive (STZ-induced) } \\
\text { mean } \pm \text { SEM } \% \text { change }\end{array}$ & $61.3 \pm 0.6^{* *} 22.11 \%$ & $15.8 \pm 0.44^{* * *}-15.5 \%$ & $79.1 \pm 0.67^{* * *}-22.67 \%$ & $25.1 \pm 0.24^{* *}-12.23 \%$ \\
\hline $\begin{array}{l}\text { Metformin mean } \pm \text { SEM } \% \\
\text { change }\end{array}$ & $52.4 \pm 3.2^{\mathrm{b}} 4.38 \%$ & $17.6 \pm 0.2^{\mathrm{b}}-5.88 \%$ & $88.9 \pm 3.6^{* * \mathrm{~b}}-13.09 \%$ & $27.1 \pm 0.23^{*}-5.24 \%$ \\
\hline Rutin mean \pm SEM $\%$ change & $53.5 \pm 2.2^{\mathrm{b}} 6.57 \%$ & $18.2 \pm 0.66^{c}-2.6 \%$ & $100.9 \pm 0.89 c-1.36 \%$ & $28.3 \pm 0.66^{\mathrm{a}}-1.04 \%$ \\
\hline $\mathrm{P}$ value & $P>0.05$ & $P=0.001$ & $\mathrm{P}<0.001$ & $\mathrm{P}<0.05$ \\
\hline
\end{tabular}

${ }^{*} \mathrm{P}<0.05$ compared to control group, ${ }^{* *} \mathrm{P}<0.01,{ }^{* * *} \mathrm{P}<0.001$ compared to control group. ${ }^{\text {ap }}<0.05$, ${ }^{\text {b }} \mathrm{P}<0.01$, ${ }^{\text {c }} \mathrm{P}<0.001$ compared to positive control group. The mean difference is significant at $\mathrm{P}<0.05 . \%$ change $=$ Percent of change compared to control group. 


\section{- Kidney tissue}

Our result presented in (table 5) showed that in positive group the level of MDA was significantly increased which amounted to $85.45 \%$ ( $p>0.01)$ when compared to control group, accompanied with significant decrease in CAT $(\mathrm{P}>0.01)$, GST $(\mathrm{P}>0.001)$ and content of GSH $(\mathrm{p}>0.01)$ which amounted to-18.46 \%,-24.76 \%,-18.49 respectively when compared to control group.

Meanwhile, groups treated with rutinand metformin showed slight increase in MDA level which amounted to $8.45 \%, 5.04 \%$ respectively which was statistically non-significant when compared to control group $(\mathrm{p}<0.05)$. Moreover rutin and metformin groups caused significant increase in CAT, GST $(p>0.01)$ and GSH $(p>0.001)$ in comparison with positive group.

Rutin group showed slight decrease in CAT (-9.7\%, p>0.05), GST $(-9.93 \%, \mathrm{p}<0.05)$ activities and GSH level $(-8.56 \%, \mathrm{p}<0.05)$. Also, metformin showed slight decrease in CAT-5.12\%, p>0.05), GST (-4.1
$\%, \mathrm{p}<0.05)$ activities and GSH elvel $(-2.73 \%, \mathrm{p}<0.05)$ when compared to control group.

Effect of rutin on levels of betatrophin in plasma and different tissues

Result in (table 6) indicated significant increase of levels of betatrophin in plasma $(13.76 \%, \mathrm{p}>0.01)$, tissues of liver $(23.6 \%, \mathrm{P}=$ $0.001)$, kidney (72.23\%, p>0.001) and pancrease (139.2\%, $\mathrm{p}>0.001$ ) in positive group when compared to control group. but this elevation was reduced in treatment with rutin (therapeutic group) and metformin (standard group).

Rutin treated group showed slight increase in plasma (4.6\%, $\mathrm{p}>0.05)$, liver $(9.5 \%, \mathrm{p}>0.05)$, kidney $(10.1 \%, \mathrm{p}>0.05)$ and pancrease $(35.3 \%, \mathrm{p}>0.05)$.

In metformin group showed slight increase which was statistically non-significant ( $\mathrm{p}>0.05)$ in plasma (3.5\%), liver (7.27\%), kidney $(7.99 \%)$ and pancrease $(16.6 \%)(p>0.05)$.

Table 5: Effect of rutin on oxidative and anti-oxidative parameters in kidney of all studied groups

\begin{tabular}{|c|c|c|c|c|}
\hline Groups & MDA (nmol/g) & Catalase (U/g) & GST(U/g) & GSH(mg/g) \\
\hline Control mean \pm SEM & $67.4 \pm 2.13$ & $19.5 \pm 0.34$ & $75.5 \pm 0.57$ & $29.2 \pm 0.08$ \\
\hline DMSO mean \pm SEM $\%$ change & $69.7 \pm 4.63 .4 \%$ & $19.4 \pm 0.65-0.51 \%$ & $70.1 \pm 2.2-7.15 \%$ & $28.4 \pm 0.33-2.73 \%$ \\
\hline $\begin{array}{l}\text { Positive (STZ-induced) mean } \pm \text { SEM } \\
\% \text { change }\end{array}$ & $125 \pm 0.67^{* *} 85.45 \%$ & $15.9 \pm 0.58^{* *}-18.46 \%$ & $56.8 \pm 0.15^{* * *}-24.76 \%$ & $23.8 \pm 0.33^{* *}-18.49$ \\
\hline Metformin mean \pm SEM $\%$ change & $70.8 \pm 7.6^{\mathrm{c} 5.04} \%$ & $18.5 \pm 0.14^{\mathrm{b}}-5.12 \%$ & $72.4 \pm .7^{b}-4.1 \%$ & $28.4 \pm 0.60^{a}-2.73 \%$ \\
\hline Rutin mean \pm SEM $\%$ change & $73.1 \pm 0.96^{c} 8.45$ & $17.6 \pm 0.33^{*}-9.7 \%$ & $68 \pm 3.6^{\mathrm{a}-9.93 \%}$ & $26.7 \pm 0.96-8.56 \%$ \\
\hline $\mathrm{P}$ value & $\mathrm{P}<0.001$ & $\mathrm{P}<0.01$ & $\mathrm{P}<0.01$ & $\mathrm{P}<0.001$ \\
\hline
\end{tabular}

${ }^{*} \mathrm{P}<0.05$ compared to control group, ${ }^{* *} \mathrm{P}<0.01,{ }^{* * *} \mathrm{P}<0.001$ compared to control group. a $\mathrm{P}<0.05$, ${ }^{b} \mathrm{P}<0.01,{ }^{\mathrm{c}} \mathrm{P}<0.001$ compared to positive control group. The mean difference is significant at $\mathrm{P}<0.05 . \%$ change $=$ Percent of change compared to control group.
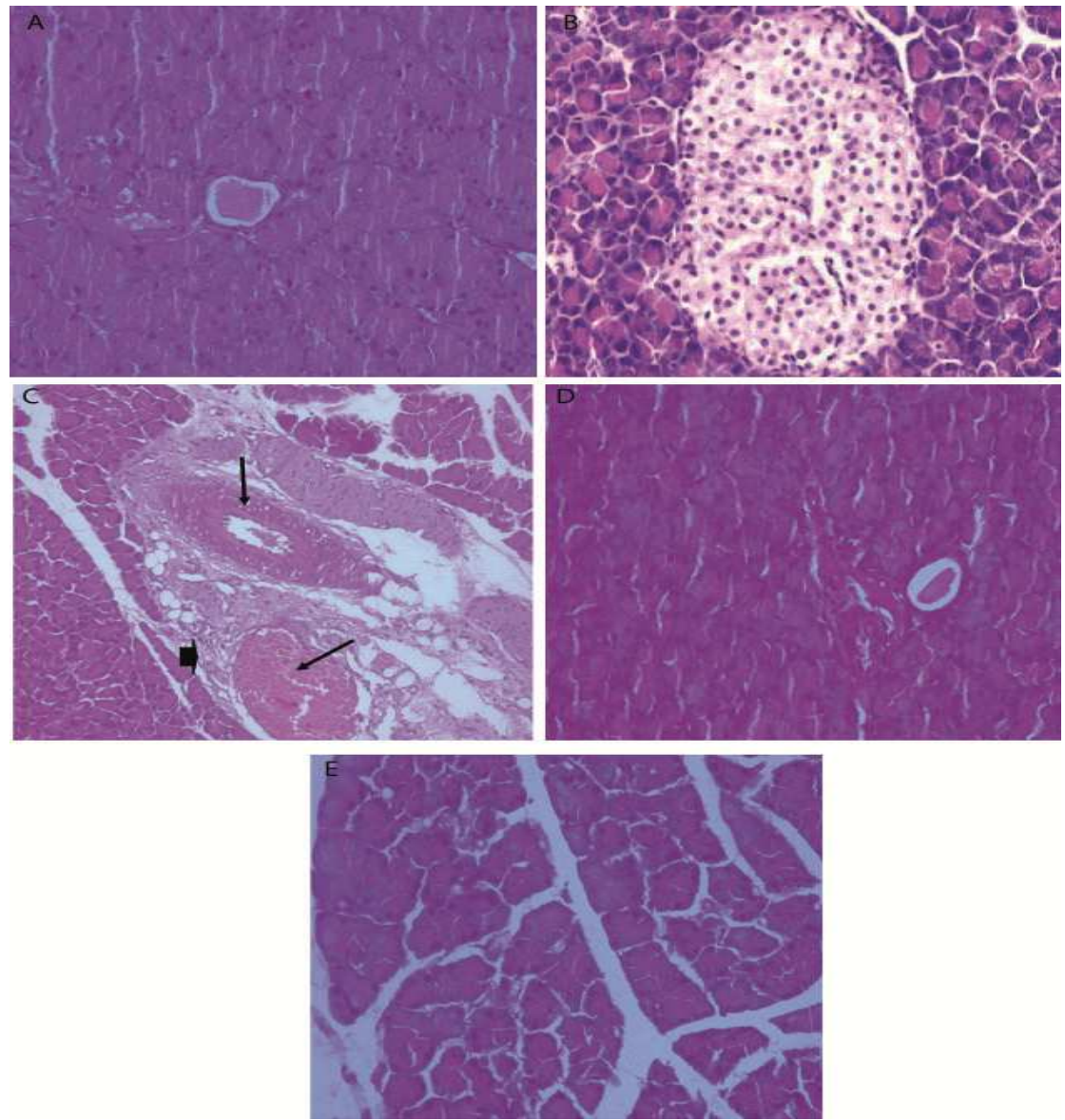

Fig. 2: Histopathological examination of pancreas tissue. A (negative control) and B (DMSO) showed apparently healthy parenchyma, note the normal pancreatic acini and islets, $C$ (Positive control) showed congestion of the blood vessel with thickened wall (arrow) together with fibrous connective tissue proliferations (arrow head), D (Metformin) showed apparently healthy parenchyma, note the normal pancreatic acini and islets, $E$ (Rutin) showed apparently healthy parenchyma, note the normal pancreatic acini and islets 
Table 6: Effect of rutin on levels of betatrophin

\begin{tabular}{|c|c|c|c|c|}
\hline \multirow[t]{2}{*}{ Groups } & \multicolumn{4}{|l|}{ Betatrophin (ng/l) } \\
\hline & Plasma & Liver & Kidney & Pancreas \\
\hline Controlmean \pm SEM & $125.0 \pm 2.4$ & $90.7 \pm 3.7$ & $97.6 \pm 0.47$ & $46.2 \pm 1.4$ \\
\hline DMSO mean \pm SEM $\%$ change & $125.7 \pm 1.20 .56 \%$ & $92.8 \pm 3.12 .3 \%$ & $100 \pm 3.12 .4 \%$ & $47.4 \pm 1.22 .5 \%$ \\
\hline $\begin{array}{l}\text { Positive (STZ-induced) } \\
\text { mean } \pm \text { SEM \% change }\end{array}$ & $142.2 \pm 0.49^{* *} 13.76 \%$ & $112.1 \pm 0.3^{* * *} 23.6 \%$ & $168.1 \pm 0.86^{* * *} 72.23 \%$ & $110.5 \pm 0.86^{* * *} 139.2 \%$ \\
\hline $\begin{array}{l}\text { Metformin mean } \pm \text { SEM } \% \\
\text { change }\end{array}$ & $129.5 \pm 4.3^{\mathrm{b}} 3.5 \%$ & $97.3 \pm 0.66^{\mathrm{b}} 7.27 \%$ & $105.4 \pm 6.6^{\mathrm{a}} 7.99 \%$ & $53.9 \pm 3.7 c 16.6 \%$ \\
\hline Rutin mean \pm SEM $\%$ change & $130.8 \pm 2.1^{\mathrm{a}} 4.6 \%$ & $100.0 \pm 2.0 *$ b $9.5 \%$ & $107.3 \pm 4.6^{\mathrm{a}} 10.1 \%$ & $62.5 \pm 0.5^{*} \mathrm{c} 35.3 \%$ \\
\hline $\mathrm{P}$ value & $\mathrm{P}<0.01$ & $P=0.001$ & $\mathrm{P}<0.001$ & $\mathrm{P}<0.001$ \\
\hline
\end{tabular}

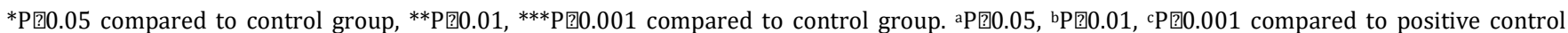
group. The mean difference is significant at PQ $0.05 . \%$ change $=$ Percent of change compared to control group.

\section{Histopathological examination}

Histology ofliver, kidney and pancreatic tissues were studied.

The normal pancrease section of control and DMSO group showed healthy n parenchyma, normal pancreatic acini and islets. In positive group showed congestion of the blood vessels with thickened wall with fibrous connective tissue proliferation. Treapeutic and standard group showed healthy parenchyma, normal acini and islets (fig. 2).

The normal histological liver section in control group and DMSO showed healty liver parenchyma, normal hepatocytes and blood sinusoids. In positive group it showed change in the portal tracts and congested hepatoportal blood vessel. In therapeutic and standard groups showed healthy liver parenchyma, normal hepatocytes and blood sinusoids (fig. 3).

The kidney section of control and DMSO group showed healthy renal parenchyma, normal glomeruli and renal tubules. Positive group showed congestion in interstitial blood vessel with thickened wall together with degeneration changes in both glomeruli and renal tubules. Therapeutic and standard group showed healthy renal parenchyma normal glomeruli and renal tubules (fig. 4).
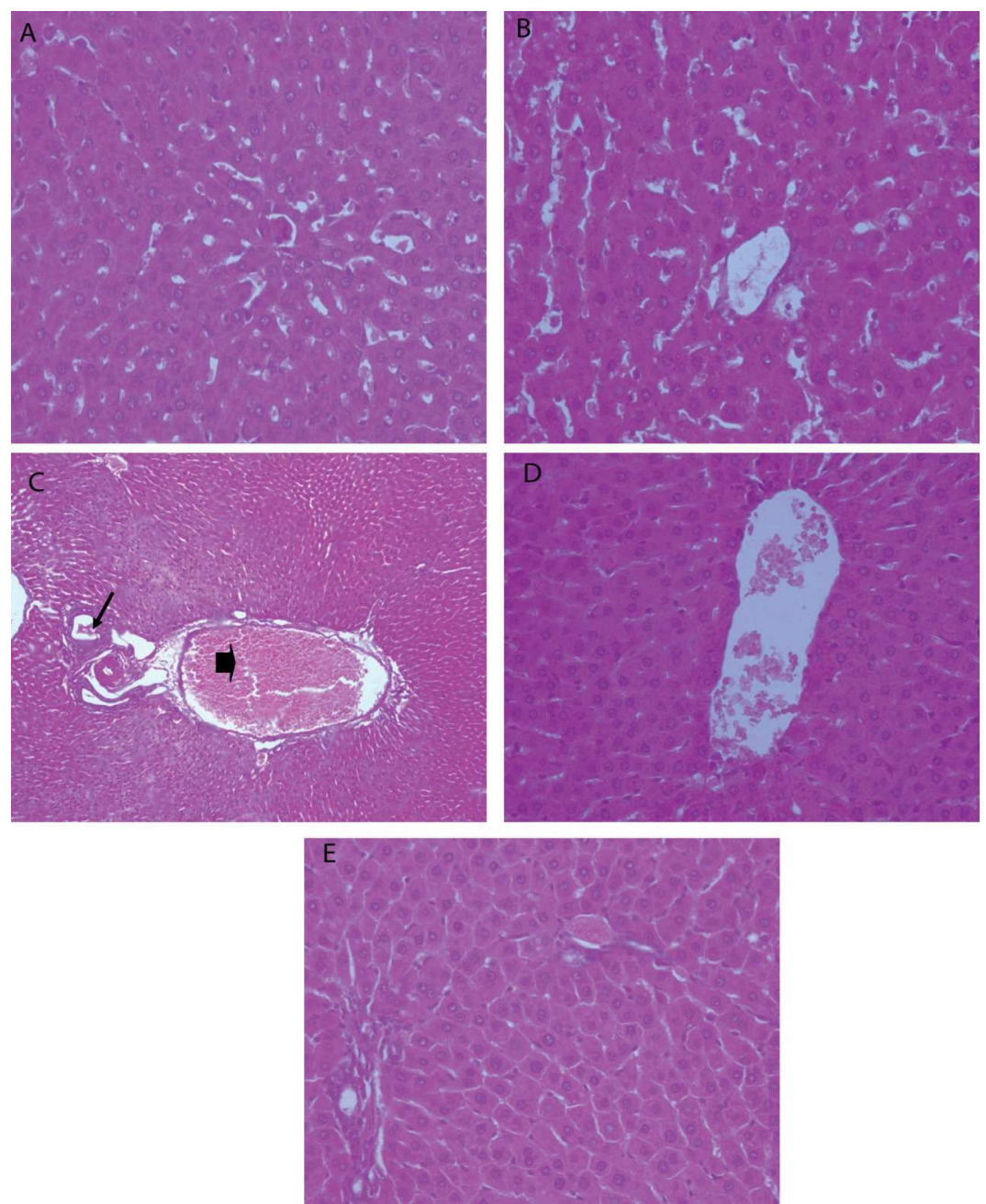

Fig. 3: Histopathological examination of liver tissue. A (negative control) and B (DMSO) showed apparently healthy liver parenchyma, note the normal hepatocytes and blood sinusoids, C (Positive control) showed changes in the portal tracts, note the congested hepatoportal blood vessel (arrow head), hyperplasia in bile duct (arrow), and leucocytic cells infiltrations, D (Metformin) showed apparently healthy liver parenchyma, note the normal hepatocytes and blood sinusoids, $\mathrm{E}$ (Rutin) showed apparently healthy liver parenchyma, note the normal hepatocytes and blood sinusoids 

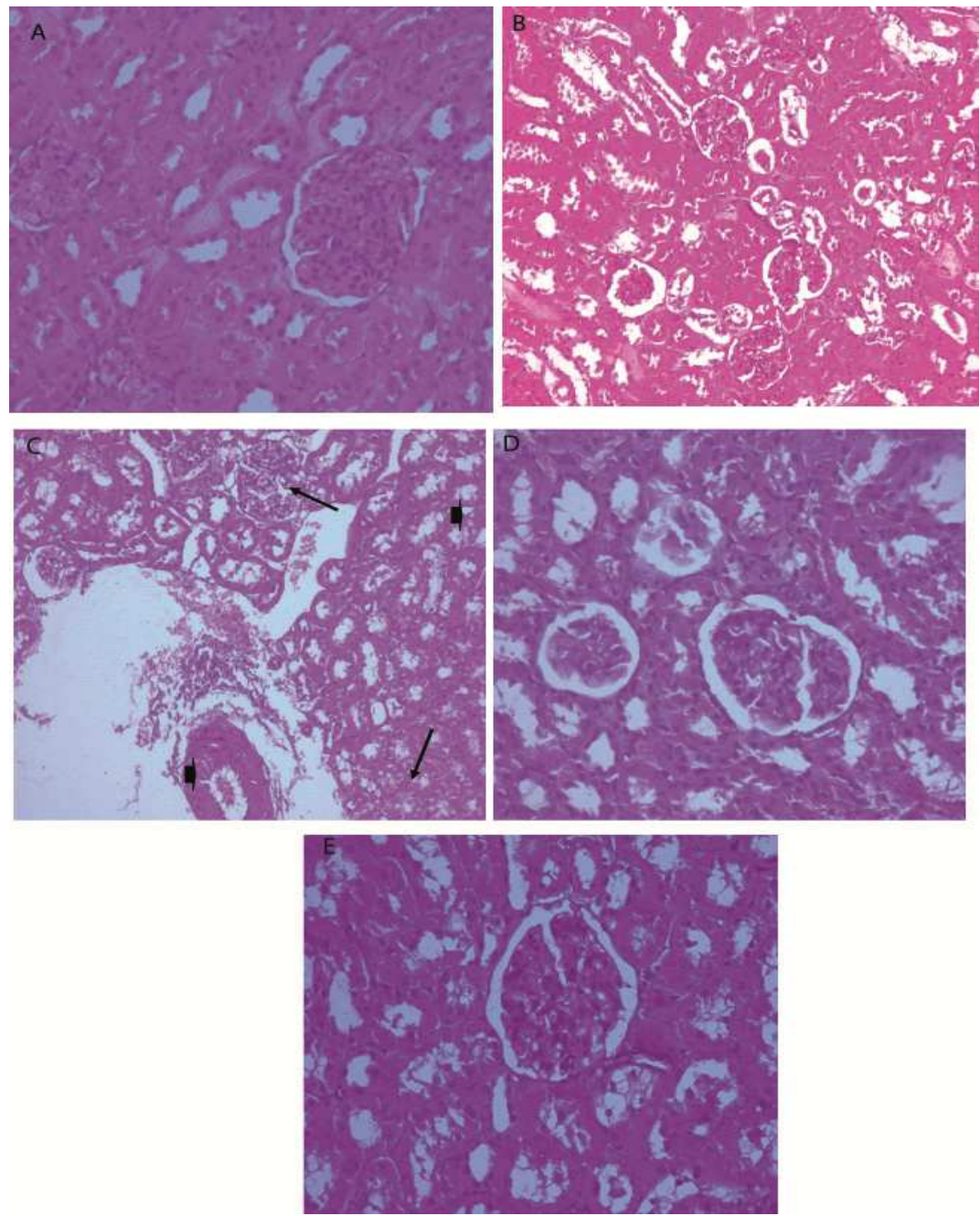

Fig. 4: Histopathological examination of kidney tissue. A (negative control) and B (DMSO) showed apparently healthy renal parenchyma, note the normal glomeruli and renal tubules, C (Positive control) showed congestion in the interstitial blood vessel with tickened wall (arrow head) together with degenerative changes in both glomeruli and renal tubules (arrows), D (Metformin) showed apparently healthy renal parenchyma, note the normal glomeruli and renal tubules, $\mathrm{E}$ (Rutin) showed apparently healthy renal parenchyma, note the normal glomeruli and renal tubules

\section{DISCUSSION}

Diabetes mellitus is a heterogeneous metabolic disease described by high blood glucose caused by defect in insulin secretion, resistance to insulin action or both [27]. Streptozotocin (STZ) is agent which affects insulin secretion it decrease it and causes a condition of insulin dependent diabetes mellitus. The selective pancreatic $\beta$-cell toxicity of STZ related to the glucose moiety in its chemical structure that enables STZ for entering the $\beta$-cell via the low affinity GLUT2 glucose transporter in the plasma membrane [28].

The present work investigate the role of rutin in treatment of type 2 diabetes induced by STZ in rats.

Our data illustrated that significant decrease $(\mathrm{p}<0.001)$ in finial body weight of diabetic induced group (positive group) when compared with control group. While group treated with rutin and metformin showed non-significant difference in final body weight in treated groups in compared to control group.

Our result in agreement with who showed significant decrease in body weight of diabetic rats in compared to control group [29].

The decrease in weight of body is related to the increase of blood glucose with decrease of insulin level, decrease of tissue proteins, and enhancement of muscle wasting in STZ diabetic animals [30]. DM is accompanied by increased glycogen breakdown, lipolysis, and gluconeogenesis and these metabolic procedures bring about muscles squandering and loss of tissue protein. The body depends on insulin as a major anabolic hormone. The inhibition of insulin secretion caused metabolic disorders of glucose and also lipids and protein. The decline and inadequacy of insulin changed over anabolism to catabolism of proteins and lipids. Building of glucose relies upon proteolysis and gluconeogenic amino acids by liver. Induction of negative nitrogen equalization credited to the catabolism of proteins and lipids; along these lines the hunger and polyphagia were expanded [31].

Rutin administration to diabetic rats improved body weight and this could be because of a superior control of the hyperglycaemic state in the diabetic rats and it is synergistic anti-inflammatory and against oxidative Properties [32]. Diminished levels of blood glucose could improve body weight in streptozotocin-diabetic rats [32].

Streptozotocin administration to rats indicated critical $(\mathrm{P}<0.001)$ expanded blood glucose. Rutin treated group exhibited a decline in plasma glucose when compared with control group.

Our outcome in accordance with who found that diabetic animals that administrated rutin had a decrease of $20.5 \%$ in the glucose levels when contrasted and beginning treatment (p[0.05) [33]

Renal illness is one of the most widely recognized and extreme difficulties of diabetes [34]. Our data found that the positive control 
group showed high elevation ( $p>0.001)$ in serum urea, creatinine, cholesterol and triglyceride ( $p>0.001)$ when compared to control group. On the other hand, treated group with rutin (therapeutic) and metformin (standard) groups showed significant decrease in comparison with positive group.

Past investigations announced that diabetic rats indicated essentially expanded serum uric acid (SUA), serum creatinine (SCr), and urea nitrogen (BUN) levels [35] and [36].

Rutin diminishes the levels of Serum Urea and Serum Creatinine in diabetes mellitus by uprightness of its antioxidant property [37].

Serum lipid levels are commonly elevated in diabetes mellitus and such an elevation speaks to a hazard factor for coronary heart disease [38].

Previous studies investigated that, there was a high increase in serum non-esterified cholesterol, triglycerides and phospholipids in STZ-induced diabetic rats, accompanied by a decrease in highdensity lipoprotein (HDL)-cholesterol [39].

Our outcomes are in accordance with who announced that total cholesterol and LDL-c levels in serum of the diabetic rats treated with Rutin were fundamentally lower in the diabetic rats $(\mathrm{p}<0.05$ and $\mathrm{p}<0.01$, respectively). These values were considerably more fundamentally diminished when contrasted with diabetic rats treated. Moreover showed the administration of rutin encourages lipid metabolism in diabetic rats so decrease levels of triglyceride and cholesterol [33].

DM is related to oxidative stress occurring as an outcome of expanded development of free radicals, such as superoxide (02-) and hydroxyl $(\mathrm{OH})$ radicals, and lower activity of antioxidant defense systems [40]. Reactive oxygen species (ROS) can negativelly influence different cell biomolecules as protein, RNA and DNA making damage to tissues and organs, so to prevent cellular damage induced by ROS, the organism has a lot of antoxidative defense system, such as the non-enzymatic (mainly GSH) and enzymatic antioxidant defenses for example (GST, CAT, SOD, GR, and GPx) which consider the key enzymes in elimination of free radicals.

Our present study approved oxidative stress in liver, kidney and pancrease and showed that oxidative stress as indicated by increased production of MDA, accompanying with decreased activities of antioxidants including GST, CAT and GSH level in positive control group when compared with control group (table $3,4,5)$.

Our data are in agreement with previous findings that showed streptozotocin (STZ)-induced diabetic rats caused increased MDA level that reflect the levels of tissue lipid peroxidation and decreased SOD activity that scavenge superoxide products in kidney tissue [36]. Glucose is oxidized to reactive ketoaldehyde and superoxide radicals. On the off chance that it isn't decayed by CAT or GSH peroxidase it causes generation of responsive hydroxyl radicals. Excess amounts of free radicals damage cellular proteins and nucleic acids by attaching to them [41].

The GST catalyzes the conjugation of glutathione to a wide range of electrophiles and support a protective mechanism against hyperglycemia mediated oxidative stress. The GST is critical in the protection of cells from reactive species because they utilize a wide variety of products of oxidative stress as substrates [42].

Rutin scavenges free radicals and decreases superoxide radical formation in addition to enhance the activity of antioxidant enzymes, glutathione peroxidase and reductase to maintain the levels of the reduced glutathione, which is a biological antioxidant [43].

Previous data showed that oral treatment with rutin to diabetic rats for a period of $6 \mathrm{w}$ showed significant ameliorative effects on GSH, CAT, SOD, GPx values in liver tissue. The elevated activities of antioxidant enzymes may act as an added additional remuneration system to keep up the cell integrity and protection against free radical damage. This showed that free radical scavenging ability of rutin could exert a beneficial action against pathogenic alterations caused 02 and $\mathrm{OH}[32]$.

Betatrophin is a hormone gotten from liver and white adipose tissue that was found to advance beta cell multiplication in a mouse model of insulin resistance induced by S961, an antagonist of the insulin receptor [44]. In our result, the betatrophin level increased in positive control group in both plasma and tissues (liver, kidney and pancrease) when compared with control group. These result in agreement with who showed that serum betatrophin was significantly higher in type 2 diabetes mellitus patients as compared to control group [45]. Also who stated that serum betatrophin levels were significantly increased in type 2 diabetic patients compared to non-diabetic subjects [46] and [47]. This correlates with the results of our study. Also, who found that high circulating betatrophin levels were discovered uniquely in patients with T2DM however not in prediabetic subjects who as of now have insulin resistance [48]. Opposed with who expressed that no connections among betatrophin and glycemic control indices for example FBG and HbA1c. Recommending that betatrophin probably won't assume a significant relation in controlling glucose homeostasis. Also, showed positive relationship of circulating betratophin levels with blood lipids levels in subjects with impaired glucose tolerance (IGT) or type 2 diabetes, and in healthy subjects. Since it is recommended that betatrophin is related with circulating low-density lipoprotein cholesterol (LDL-C), highdensity lipoprotein cholesterol (HDL-C), and triglyceride (TG) probably via the respectively different mechanisms [49].

The formation of betatrophin in liver is highly produced under insulin resistance caused by uptake of an insulin receptor blocker such as was transporter 2 (SGLT2) inhibitors [50].

Our histopathological examination showed severe alterations of liver, kidney and pancreatic tissues were observed in untreated diabetic rats. Also, rutin attenuated the histopathological changes in STZ diabetic rats.

Our results are in accordance with who stated that pancreatic tissues of diabetic control rats showed a decrease of Langerhans islet size and multiple degeneration and injuries. In addition to, the number of $\beta$-cells was reduced, and some necrosis and destruction were found [51].

Also, who stated that the structure of renal tissue was damaged in STZ diabetic rats [36].

Generally, the present obtained findings confirm that the influences of rutin is attributed to the antioxidant properties.

\section{CONCLUSION}

Natural food and medicinal plants and supplements have the potential to become valuable complementary therapy in the treatment of DM and its complications. The present study evaluated the hypoglycemic activitiy of rutin on diabetic male rats. Based on the present experimental data, it can be concluded that this rutin improve the physiological and histological changes induced by STZ in the experimental animals.

\section{AUTHORS CONTRIBUTIONS}

All the author have contributed equally.

\section{CONFLICT OF INTERESTS}

\section{Declared none}

\section{REFERENCES}

1. Trivedi B, Mazumdar J, Bhatt D, Hemavathi KJ. Effect of shilajit on blood glucose and lipid profile in alloxan-induced diabetic rats. Indian J Pharmacol 2004;36:373-6.

2. Doux SP, Woodley SE, Palton NJ, Wilson GL. Mechanism of nitrosourea induced cell damage: alteration in DNA. Diabetes 1986;35:866-72.

3. Portha B, Blondel O, Serradas P, McEvoy R, Giroix MH, Kergoat $\mathrm{M}$, et al. The rat models of non-insuindependant diabetes induced by neonatal streptozotocin. Diabete Metab 1989;15:61-75.

4. Cao J, Zhang Y, Chen W, Zhao X. The relationship between fasting plasma concentrations of selected flavonoids and their ordinary dietary intake. Br J Nutr 2010;103:249-55.

5. Scholz S, Williamson G. Interactions affecting the bioavailability of dietary polyphenols in vivo. Int J Vitam Nutr Res 2007;77:224-35. 
6. Mamani Matsuda M, Kauss T, Al-Kharrat A, Rambert J, Fawaz F, Thiolat $\mathrm{D}$, et al. Therapeutic and preventive properties of quercetin in experimental arthritis correlate with decreased macrophage inflammatory mediators. Biochem Pharmacol 2006;72:1304-10.

7. Valerio DA, Georgetti SR, Magro DA, Casagrande R, Cunha TM, Vicentini FT. Quercetin reduces inflammatory pain: inhibition of oxidative stress and cytokine production. J Nat Prod 2009;72:1975-9.

8. McAnulty SR, McAnulty LS, Nieman DC, Quindry JC, Hosick PA, Hudson $\mathrm{MH}$, et al. Chronic quercetin ingestion and exerciseinduced oxidative damage and inflammation. Appl Physiol Nutr Metab 2008;33:254-62.

9. Inam M, Altinisik M, Bilgin MD. The effect of quercetin on renal ischemia and reperfusion injury in the rat. Cell Biochem Funct 2002;20:291-6.

10. Huk I, Brovkovych V, Nanobash Vili J, Weigel G, Neumayer C, Partyka L, et al. Bioflavonoid quercetin scavenges superoxide and increases nitric oxide concentration in ischaemiareperfusion injury: an experimental study. $\mathrm{Br}$ J Surg 1998;85:1080-5.

11. Masiello P, Broca C, Gross R, Roye M, Manteghetti M, Hillaire Buys D, et al. Experimental NIDDM: development of a new model in adult rats administered streptozotocin and nicotinamide. Diabetes 1998;47:224-9.

12. Kim MJ, Lim Y. Protective effect of short-term genistein supplementation on the early stage in diabetes-induced renal damage. Mediators Inflamm 2013;2013:510212.

13. Kamalakkannan N, Stanely Mainzen Prince $P$. The antihyperglycaemic and antioxidant effect of rutin, a polyphenolic flavonoid, in streptozotocin-induced diabetic wistar rats. Basic Clin Pharmacol Toxicol 2006;98:97-103.

14. Kiliari EK, Mullapudi B, Moka PV, Silakabattini K, Nelli G. Inhibition of DPP-IV activity and enhancement of GLP1expression by aqueous peel extract of punicagranatumin albino wistar rats. Globale Trends Pharm Sci 2014;2:1528-41.

15. Pruden EL, McPherson RA, Fuhrman SA. Clinical guide to laboratory test-Ed. Tiet N. W./Saunders W. B. Company. 3th ed. Section 1: General Clin Test; 1995. p. 268-73.

16. Kaplan A, Urea, Kaplan A. Clin chem the C. V. mosby Co. St louis. Toronto Princeton; 1984. p. 1257-60, 437, 418.

17. Kaplan A. Urea, Kaplan A. Clin chem the C. V. mosby Co. StLouis. Toronto Princeton; 1984. p. 1257-60, 437, 418.

18. Young DS. Effects of disease on clinical lab. Tests, $4^{\text {th }}$ ed., AACC; 2001.

19. Stein EA. Lipids, lipoproteinsand apolipoproteins. In: Tietz NW. ed. Fundamentals of clinical chemistry. $3^{\text {rd }}$ ed. Philadephia: WB Saunders; 1987. p. 448-81.

20. Ohkawa H, Ohishi N, Yagi K. Assay for lipid peroxides in animal tissues by thiobarbituric acid reaction. Anal Biochem 1979;95:351.

21. Beutler E, Duron 0, Kelly MB. Improved method for the determination of blood glutathione. J Lab Clin Med 1963;61:882-90.

22. Habig WH, Pabst MJ, Jakoby WB. Glutathione S-transferases: the first enzymatic step in mercapturic acid formation. J Biol Chem 1974;249:7130-9.

23. Aebi H. Catalase in vitro. Methods Enzymol 1984;105:121-6.

24. Fossati P, Prencipe L, Berti G. Use of 3,5-dichloro-2hydroxybenzenesulfonic acid/4-aminophenazone chromogenic system in direct enzymic assay of uric acid in serum and urine. Clin Chem 1980;26:227-31.

25. Bancroft J, Gamble M. Theory and practice of Histological Technique 4th Ed. Churchill Livingston, New York: London, San Francisco, and Tokyo; 2008.

26. SPSS. Statistical package for social science, computer software, Ver. 16. London, UK: SPSS Company; 2008.

27. Duchatelet S, Zucman SC, Laforgue DD, Blanc H, Timsit J, Julier C. FCRL3-169CT functional polymorphism in type 1 diabetes and autoimmunity traits. Biomed Pharmacother 2007;7:62153.

28. Elsner M, Guldbakke B, Tiedge M, Munday R, Lenzen S. Relative importance of transport and alkylation for pancreatic beta-cell toxicity of streptozotocin. Diabetologia 2000;43:1328-33.
29. Guex CG, Reginato FZ, de Jesus PR, Brondani JC, Lopes GHH, Bauermann LF. Antidiabetic effects of oleaeuropaea L. leaves in diabetic rats induced by high-fat diet and low-dose streptozotocin. J Ethnopharmacol 2019;235:1-7.

30. Cheng D, Liang B, Li Y. Antihyperglycemic effect of ginkgo biloba extract in streptozotocin-induced diabetes in rats. BioMed Res Int 2013;1:1-7.

31. Ewenighi C, Dimkpa U, Onyeanusi J, Onoh L, Onoh G, Ezeugwu U. Estimation of glucose level and body weight in alloxan induced diabetic rat treated with aqueous extract of garcinia kola seed. Ulutas Med J 2015;1:26-30.

32. Al-Enazi MM. Combined therapy of rutin and silymarin has more protective effects on streptozotocin-induced oxidative stress in rats. J Appl Pharm Sci 2014;4:21-8.

33. Chielle EO, Bonfanti G, De Bona KS, Cargnelutti LO, Bitencourt PER, Da Silva PS, et al. Rutin restores adenosine deaminase activity in serum and the liver and improves biochemical parameters in streptozotocin-induced diabetic rats. Rev Bras Plants Med Campinas 2016;18:273-8.

34. Tierney LM, McPhee SJ, Papadakis MA. Current medical diagnosis and treatment. International edition. NewYork: Lange Medical Books/McGraw-Hill; 2002. p. 1203-15.

35. Ran J, Xu G, Ma H, Xu H, Liu Y, Tan R, et al. Febuxostat attenuates renal damage besides exerting hypouricemic effect in streptozotocin-induced diabetic rats. Int J Nephrol 2017;1-9. https://doi.org/10.1155/2017/2739539

36. Jia Q, Yang R, Liu XF, Ma SF, Wang L. Genistein attenuates renal fibrosis in streptozotocin-induced diabetic rats. Mol Med Reports 2019;19:423-31.

37. Sattanathan K, Dhanapal CK, Umarani R, Manavalan R. Beneficial effects of rutin on nephropathy: a serious complication associated with diabetes. J Pharm Res 2011;4:3826-8.

38. Muthulingam M. Antidiabetic efficacy of leaf extracts of asteracanihalongifolia (Linn.) nees. onalloxan induced diabetics in male albino wistar rats. Int J Pharm Biomed Res 2010;1:8-34.

39. Ahmed I, Lakhani MS, Gillett M, John A, Raza H. Hypotriglyceridemia and hypo-cholestrolemic effects of antidiabetic momordicacharantia (karela) fruit extract in streptozotocin-induced diabetic rats. Diabetes Res Clin Pract 2001;51:155-61.

40. Martin Gallan P, Carrascosa A, Gussinye M, Dominguez C. Biomarkers of diabetes-associated oxidative stress and antioxidant status in young diabetic patients with or without subclinical complications. Free Radical Biol Med 2003;34:156374.

41. Maritim AC, Sanders RA, Watkins JB. Diabetes, oxidative stress and antioxidants: a review. J Biochem Mol Toxicol 2003;17:2438.

42. Bekris LM, Shephard C, Peterson M, Hoehna J, Van Yserloo B, Rutledge E, et al. Glutathione-s-transferase M1 and T1 polymorphisms and associations with type 1 diabetes age-atonset. Autoimmunity 2005;38:567-75.

43. Kamalakkanan N, Rajadurai M, Stanely Mainzen Prince P. Effect of Aeglemarmelos fruits on normal and streptozotocin diabetic wistar rats. J Med Food 2006;6:93-8.

44. Yi P, Park JS, Melton DA. Betatrophin: a hormone that controls pancreatic $\beta$ cell proliferation. Cell 2013;153:747-58.

45. El-Ghandour AH, El-Bendary AS, Shahba AA, Soliman GA. Study of serum betatrophin level in the patients of type 2 diabetes mellitus. Egyptian J Hosp Med 2019;74:1809-16.

46. Abu Farha M, Al-Khairi I, Cherian P. Increased ANGPTL3, 4 and ANGPTL8/betatrophin expression levels in obesity and T2D. Lipids Health Dis 2016;15:181.

47. Hu H, Wenjun S, Shuqin Y, Xiafei H. Increased circulating levels of betatrophin in newly diagnosed type 2 diabetic patients. Diabetes Care 2014;37:2718-22.

48. Tabak AG, Herder C, Rathmann W, Brunner EJ, Kivimaki M. Prediabetes: a high-risk state for diabetes development. Lancet 2012;379:2279-90.

49. Wang L, Jun S, Chuan W. Circulating levels of betatrophin and irisin are not associated with pancreatic $\beta$-cell function in previously diagnosed type 2 diabetes mellitus patients. J Diabetes Res 2016;6:8. 
50. Ferrannini E, Muscelli E, Frascerra S, Baldi S, Mari A, Heise T, et al. Metabolic response to sodiumglucosecotransporter 2 inhibition in type 2 diabetic patients. J Clin Invest 2014;124:499-508.
51. Almalki DA, Alghamdi SA, Al-Attar AM. Comparative study on the influence of some medicinal plants on diabetes induced by streptozotocin in male rats. BioMed Res Int 2019;1-11. https://doi.org/10.1155/2019/3596287 